If you wish to distribute this article to others, you can order high-quality copies for your colleagues, clients, or customers by clicking here.

Permission to republish or repurpose articles or portions of articles can be obtained by following the guidelines here.

The following resources related to this article are available online at www.sciencemag.org (this infomation is current as of January 12, 2011 ):

Updated information and services, including high-resolution figures, can be found in the online version of this article at:

http://www.sciencemag.org/content/312/5776/1016.full.html

This article has been cited by 34 article(s) on the ISI Web of Science

This article has been cited by 2 articles hosted by HighWire Press; see: http://www.sciencemag.org/content/312/5776/1016.full.html\#related-urls

This article appears in the following subject collections:

Geochemistry, Geophysics

http://www.sciencemag.org/cgi/collection/geochem_phys 


\section{Drilling to Gabbro in Intact Ocean Crust}

Douglas S. Wilson, ${ }^{1 *} \dagger \ddagger \S$ Damon A. H. Teagle, ${ }^{2 *} \dagger \ddagger$ Jeffrey C. Alt, ${ }^{3 *} \ddagger$ Neil R. Banerjee, ${ }^{4 *} \dagger \ddagger$ Susumu Umino, ${ }^{5 *} \dagger$ Sumio Miyashita, ${ }^{6} \ddagger$ Gary D. Acton, ${ }^{7 *}$ Ryo Anma, ${ }^{8} \ddagger$ Samantha R. Barr, ${ }^{9 *}$ Akram Belghoul, ${ }^{10} \dagger$ Julie Carlut, ${ }^{11} \ddagger$ David M. Christie, ${ }^{12} \ddagger$ Rosalind M. Coggon, ${ }^{3 *} \ddagger$ Kari M. Cooper, ${ }^{7 *}$ Carole Cordier, ${ }^{13} \dagger$ Laura Crispini, ${ }^{14 *} \dagger$ Sedelia Rodriguez Durand, ${ }^{15} \dagger$ Florence Einaudi, ${ }^{10 *} \dagger$ Laura Galli, ${ }^{16} \dagger \ddagger$ Yongjun Gao, ${ }^{17} \dagger$ ]örg Geldmacher, ${ }^{18} \dagger$ Lisa A. Gilbert, ${ }^{19} \dagger$ Nicholas W. Hayman, ${ }^{20} \ddagger$ Emilio Herrero-Bervera, ${ }^{21} \dagger$ Nobuo Hirano,${ }^{23} \ddagger$ Sara Holter, ${ }^{24} \dagger$ Stephanie Ingle, ${ }^{22} \ddagger$ Shijun jiang, ${ }^{25 *}$ Ulrich Kalberkamp, ${ }^{26 *}$ Marcie Kerneklian, ${ }^{27 *}$ Jürgen Koepke, ${ }^{28} \ddagger$ Christine Laverne, ${ }^{29 *} \dagger \ddagger$ Haroldo L. Lledo Vasquez, ${ }^{30} \dagger$ John Maclennan, ${ }^{31} \ddagger$ Sally Morgan, ${ }^{32} \ddagger$ Natsuki Neo, ${ }^{6} \ddagger$ Holly j. Nichols, ${ }^{18} \dagger$ Sung-Hyun Park, ${ }^{33} \ddagger$ Marc K. Reichow, ${ }^{9} \ddagger$ Tetsuya Sakuyama, ${ }^{34} \dagger$ Takashi Sano, ${ }^{35} \dagger$ Rachel Sandwell, ${ }^{36 *}$

Birgit Scheibner, ${ }^{37} \ddagger$ Chris E. Smith-Duque, ${ }^{2} \dagger$ Stephen A. Swift, ${ }^{38} \ddagger$ Paola Tartarotti, ${ }^{16 *} \dagger$ Anahita A. Tikku, ${ }^{39} \ddagger$ Masako Tominaga, ${ }^{40} \dagger \ddagger$ Eugenio A. Veloso, ${ }^{8} \dagger \ddagger$ Toru Yamasaki, ${ }^{41} \ddagger$

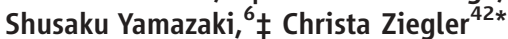

Sampling an intact sequence of oceanic crust through lavas, dikes, and gabbros is necessary to advance the understanding of the formation and evolution of crust formed at mid-ocean ridges, but it has been an elusive goal of scientific ocean drilling for decades. Recent drilling in the eastern Pacific Ocean in Hole 1256D reached gabbro within seismic layer 2, 1157 meters into crust formed at a superfast spreading rate. The gabbros are the crystallized melt lenses that formed beneath a mid-ocean ridge. The depth at which gabbro was reached confirms predictions extrapolated from seismic experiments at modern mid-ocean ridges: Melt lenses occur at shallower depths at faster spreading rates. The gabbros intrude metamorphosed sheeted dikes and have compositions similar to the overlying lavas, precluding formation of the cumulate lower oceanic crust from melt lenses so far penetrated by Hole 1256D.

$\mathrm{O}$ ean crust formed at mid-ocean ridges covers more than $60 \%$ of Earth's surface, yet our understanding of its accretion at mid-ocean ridges and evolution on the ridge flanks has been severely limited by the extreme difficulty of direct sampling. Remote geophysical measurements have produced longstanding models for the structure of ocean crust, including the size and shape of magma chambers at mid-ocean ridges (1-3), but the lack of direct sampling of in situ crust has prevented testing these models. Gabbros are coarse-grained mafic rocks commonly formed from slow cooling of magma chambers beneath mid-ocean ridges. Drilling a complete section of upper oceanic crust down to gabbro will enable testing models for the formation and structure of oceanic crust (4-9).

Multichannel reflection seismic (MCS) profiling of active intermediate and fast-spreading ridges commonly shows bright reflectors at depths of 1 to $4 \mathrm{~km}$ that have the properties expected for a thin (20- to 100-m) lens of partial melt (10-14). These melt lenses extend less than $1 \mathrm{~km}$ from the ridge axis and crystallize to form gabbroic rocks. The depth to the reflectors decreases as spreading rate increases (Fig. 1) $(15,16)$; it is controlled by the rate of magma supply from below and hydrothermal cooling by seawater from above (7). Melt lenses are hypothesized to play a critical role in the formation of the lower oceanic crust. According to the "gabbro glacier" model (6-8), as oceanic crust spreads away from the ridge axis, the accumulated crystal residues in these melt lenses subside to form the lower ocean crust, which is the major portion of the crust. Alternative models, however, argue that the lower crust is formed by injection of sills at various depths $(5,17)$ and that the geophysically imaged melt lens is simply the most shallow intrusion.

In addition to geophysical studies, our understanding of oceanic basement and particularly the plutonic portion of the crust comes from observations of ancient oceanic rocks exposed on land in ophiolites, seafloor observations of active ridges and deep-sea tectonic exposures, and drilling. The origin of ophiolites in marginal basins and the disruption of tectonically exposed lower crust, however, make the relevance of these observations to intact ocean crust questionable. Previous deep drilling in intact crust has only once penetrated the transition from lavas to dikes, in Ocean Drilling Program (ODP) Hole 504B, which reached a total depth of $1836 \mathrm{~m}$ sub-basement (msb) (18). Unfortunately, Hole 504B failed to penetrate the dike-gabbro boundary because of hostile drilling conditions in fractured dikes at high temperatures. Although fault-exposed lower ocean crust has been drilled in several places (19-23), the geological context of such cores is often unknown. The critical transition from dikes to gabbros has previously never been cored.

Deep drilling into basement at Site $\mathbf{1 2 5 6 .}$ Recently, Integrated Ocean Drilling Program (IODP) Expeditions 309 and 312 deepened Hole 1256D in the eastern Pacific to $1507 \mathrm{~m}$ below seafloor (mbsf) $(1257 \mathrm{msb}$; msb = mbsf - sediment thickness), drilling through lavas, the underlying sheeted dike complex, and into gabbroic rocks. This is the first penetration of the dike-gabbro boundary in intact ocean crust since the inception of deep sea drilling nearly 40 years ago. Hole 1256D thus provides unique samples of the lithologic transitions in the upper crust, from lavas to dikes and from dikes to gabbros. The dike-gabbro boundary is key to understanding crustal structure and the interplay between magmatic accretion and hydrothermal cooling.

The recognition of an interval of superfast spreading rates, up to $220 \mathrm{~mm} /$ year full rate (24), on the Cocos-Pacific plate boundary between 19 and 12 million years ago (Ma) led to the choice of ODP Site 1256 (Fig. 2) as the optimal site for deep drilling (25). Scientific ocean drilling mainly targets relatively soft, easily cored sediments. In contrast, coring into the underlying, much harder, basaltic basement is less common and most holes are shallow

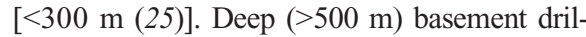
ling requires a substantial commitment of resources but yields major scientific rewards by sampling otherwise inaccessible regions of Earth's interior. A deep drill hole at the fastest possible spreading rate tests the prediction that a melt lens reflector is more shallow at higher spreading rates, and also minimizes the drilling needed to sample an intact section from lavas to gabbros, because the upper crust is thinner. This is an important advantage considering the cost, time, and technical challenges of deep drilling. Assuming that $\sim 300 \mathrm{~m}$ of lavas flowed off axis, the depth to gabbros was predicted to be between 1025 to $1300 \mathrm{msb}$ (1275 to $1550 \mathrm{mbsf}$ ) at Site 1256 (26).

Drilling at Site 1256 was initiated in 2002 on ODP Leg 206 when Hole 1256D was drilled through $250 \mathrm{~m}$ of sediment and $502 \mathrm{~m}$ into basement (25). Coring continued to $1255 \mathrm{mbsf}$ in 2005 by IODP Expedition 309, and recently Expedition 312 deepened the hole to 1507.1 mbsf and into gabbros (27). Almost 5 months at Site 1256 were required to achieve the operational and scientific objectives.

Results from drilling. Gabbros were first intersected at $1157 \mathrm{msb}$ (1407 mbsf), within the predicted target zone (26). The uppermost crust at Site 1256 is composed of a $\sim 100$-m-thick sequence of lava dominated by a single flow up to $75 \mathrm{~m}$ thick, requiring at least this much seafloor relief to pool the lava. On modern fastspreading ridges, such topography does not normally develop until 5 to $10 \mathrm{~km}$ from the axis (28). The lavas immediately below include 
sheet and massive flows, and minor pillow flows. Subvertical, elongate, flow-top fractures filled with quenched glass and hyaloclastite in these lavas indicate flow lobe inflation requiring eruption onto a subhorizontal surface off

${ }^{1}$ Department of Earth Science and Marine Science Institute, University of California, Santa Barbara, CA 93106, USA. ${ }^{2}$ National Oceanography Centre, Southampton, University of Southampton, S014 3ZH, UK. ${ }^{3}$ Department of Geological Sciences, University of Michigan, Ann Arbor, MI 48109, USA. ${ }^{4}$ Integrated Ocean Drilling Program, Texas A\&M University, College Station, TX 77845, USA. ${ }^{5}$ Department of Biology and Geosciences, Shizuoka University, Shizuoka 422-8529, Japan. ${ }^{6}$ Department of Geology, Niigata University, Niigata 950-2181, Japan. ${ }^{7}$ Department of Geology, University of California, Davis, CA 95616, USA. ${ }^{8}$ Graduate School of Life and Environmental Sciences, University of Tsukuba, Ibaraki 305-8572, Japan. ${ }^{9}$ Department of Geology, University of Leicester, Leicester LE1 7RH, UK. ${ }^{10}$ Laboratoire de Géophysique et d'Hydrodynamique en Forage, Institut des Sciences de la Terre, de l'Environnement et de l'Espace de Montpellier, 34095 Montpellier, France. ${ }^{11}$ Laboratoire de Géologie, École Normale Supérieure, 75231 Paris, France. ${ }^{12}$ College of Oceanic and Atmospheric Sciences, Oregon State University, Corvallis, OR 97331-5503, USA. ${ }^{13}$ Institut Universitaire Européen de la Mer (IUEM), CNRS/UBO F-29280, Plouzané, France. ${ }^{14}$ Dipartimento per lo Studio del Territorio e delle sue Risorse, Università di Genova, 16132 Genova, Italy. ${ }^{15}$ Department of Earth Sciences, Florida International University, Miami, FL 33199, USA. ${ }^{16}$ Department of Earth Sciences, Università di Milano, 20133 Milano, Italy. ${ }^{17}$ Department of Geosciences, University of Houston, Houston, TX 77204, USA. ${ }^{18}$ Leibniz Institute for Marine Sciences Kiel, Instituts für Meereskunde-Forschungszentrums für Marine Geowissenschaften, 24148 Kiel, Germany. ${ }^{19}$ Maritime Studies Program, Williams College and Mystic Seaport, Mystic, CT 06355, USA. ${ }^{20}$ Division of Earth and Ocean Sciences, Duke University, Durham, NC 27708, USA. ${ }^{21}$ Hawaii Institute of Geophysics and Planetology, ${ }^{22}$ Department of Geology and Geophysics/School of Ocean and Earth Science and Technology, University of Hawaii at Manoa, Honolulu, HI 96822, USA

${ }^{23}$ Graduate School of Environmental Studies, Tohoku University, Sendai $980-8579$, Japan. ${ }^{24}$ Department of Geology, University of St. Thomas, St. Paul, MN 55105, USA. ${ }^{25}$ Department of Geological Sciences, Florida State University, Tallahassee, FL 32306-4100, USA. ${ }^{26}$ Bundesanstalt für Geowissenschaften und Rohstoffe, 30655 Hannover, Germany. ${ }^{27}$ Department of Geology and Geophysics, University of Utah, Salt Lake City, UT 84112, USA. ${ }^{28}$ Institut für Mineralogie, Universität Hannover, 30167 Hannover, Germany. ${ }^{29}$ Laboratoire de Pétrologie Magmatique, Université Paul Cézanne AixMarseille III, 13397 Marseille 20, France. ${ }^{30}$ Department of Geoscience, University of Las Vegas, Las Vegas, NV 89154-4010, USA. ${ }^{31}$ Department of Earth Sciences, University of Cambridge, Cambridge CB2 3EQ, UK. ${ }^{32}$ School of Earth Sciences, University of Leeds, West Yorkshire LS2 91T, UK. ${ }^{33}$ Polar Research Institute, Incheon 406-840, Korea. ${ }^{34}$ Department of Earth and Planetary Science, University of Tokyo, Tokyo 113-0033, Japan. ${ }^{35}$ Department of Geology and Paleontology, The National Science Museum, Tokyo 169-0073, Japan. ${ }^{36}$ Department of Earth and Planetary Sciences, Macquarie University, Sydney 2109, Australia. ${ }^{37}$ Institut für Mineralogie und Geochemie, Universität Karlsruhe, 76131 Karlsruhe, Germany. ${ }^{38}$ Department of Geology and Geophysics, Woods Hole Oceanographic Institution, Woods Hole, MA 02543, USA. ${ }^{39}$ Department of Earth and Environmental Sciences, Rensselaer Polytechnic Institute, Troy, NY 12180-3590, USA. ${ }^{40}$ Department of Oceanography, Texas A\&M University, College Station, TX 77843-3146, USA. ${ }^{41}$ Department of Earth and Planetary Sciences, Hokkaido University, Hokkaido 060-0810, Japan. ${ }^{42}$ Department of Earth Sciences, Boston University, Boston, MA 02215, USA.

*Ocean Drilling Program (ODP) Leg 206 Shipboard Scientific Party.

†Integrated Ocean Drilling Program (IODP) Expedition 309 Shipboard Scientific Party.

†IODP Expedition 312 Shipboard Scientific Party. §To whom correspondence should be addressed. E-mail: dwilson@geol.ucsb.edu axis (29). Thus, we estimate a total thickness of off-axis lavas of $284 \mathrm{~m}$, close to the assumed thickness. Sheet flows and massive lavas that erupted at the ridge axis make up the remaining extrusive section down to 1004 mbsf, before a lithologic transition is marked by subvertical intrusive contacts and mineralized breccias. Below 1061 mbsf, subvertical intrusive contacts are numerous, indicating the start of a relatively thin, 350 -m-thick, sheeted dike complex that is dominated by massive basalts. Some basalts have doleritic textures, and many are cross-cut by subvertical dikes with common strongly brecciated and mineralized chilled margins. There is no evidence from core or from geophysical wireline logs for substantial tilting of the dikes. This is consistent with seismic reflection images of subhorizontal reflectors in the lower extrusive rocks that are continuous for several kilometers across the site (30).

There is a stepwise increase in alteration grade downward from lavas into dikes, with low-temperature phases $\left(<150^{\circ} \mathrm{C}\right.$; phyllosilicates and iron oxyhydroxides) in the lavas giving way to dikes partially altered to chlorite and other greenschist minerals (at temperatures $>\sim 250^{\circ} \mathrm{C}$; Fig. 3). Within the dikes, the alteration intensity and grade increase downward, with actinolite more abundant than chlorite below $1300 \mathrm{mbsf}$ and hornblende present below 1350 mbsf indicating temperatures approaching $\sim 400^{\circ} \mathrm{C}$. The dikes have substantially lower porosity (mostly 0.5 to

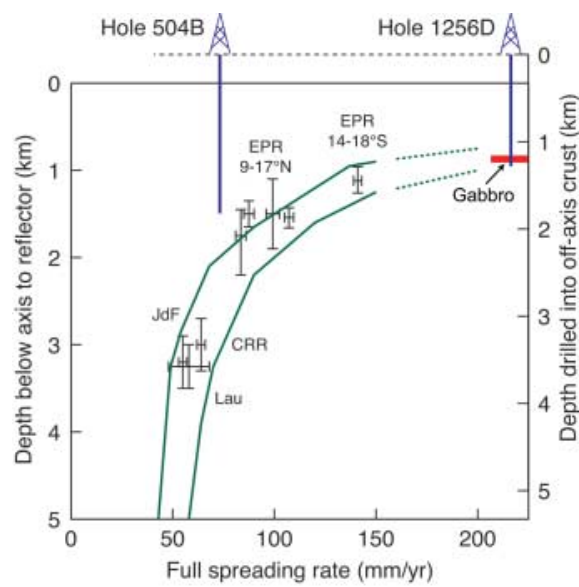

Fig. 1. Depth to axial melt-lens reflector plotted against spreading rate. Depth versus spreading rate predictions from two models of Phipps Morgan and Chen (7) are shown, extrapolated subjectively to $200 \mathrm{~mm} /$ year (dashed lines). Penetration to date in Holes 504B and 1256D is shown by solid vertical lines, with the depth at which gabbros were intersected indicated in red. According to core descriptions, a thickness of $\sim 300$ m of offaxis lavas is shown for Hole 1256D and assumed for Hole 504B. JdF, Juan de Fuca Ridge; Lau, Valu Fa Ridge in Lau Basin; CRR, Costa Rica Rift. [Image modified from $(15,16)$ ]
$2 \%$ ) and higher $P$-wave velocities and thermal conductivity than the lavas; porosity decreases and $P$-wave velocity increases as depth increases in the dikes.

In the lower $\sim 60 \mathrm{~m}$ of the sheeted dikes (1348 to $1407 \mathrm{mbsf}$ ), basalts are partially to completely recrystallized to distinctive granoblastic textures resulting from contact metamorphism by underlying gabbroic intrusions (Fig. 4). Gabbro and trondhjemite dikes intrude into sheeted dikes at 1407 mbsf, marking the top of the plutonic complex. Two major bodies of gabbro were penetrated beneath this contact, with the 52-m-thick upper gabbro separated from the 24-m-thick lower gabbro by a 24-m screen of granoblastic dikes (Fig. 4). The upper gabbro comprises gabbros, oxide gabbros, quartz-rich oxide diorites, and small trondhjemite dikelets. These rocks are moderately to highly altered by hydrothermal fluids to actinolitic hornblende, secondary plagioclase, epidote, chlorite, prehnite, and laumontite. The relative ferocity of hydrothermal alteration increases with grain size and proximity to intrusive boundaries. The lower gabbro comprises gabbro, oxide gabbro, and subordinate orthopyroxenebearing gabbro and trondhjemite that are similarly altered, and has clear intrusive contacts with the overlying granoblastic dike screen. Partially resorbed, stoped dike clasts are entrained within both the upper and lower margins of the lower gabbro (Fig. 4G). The lowermost rock recovered from Hole 1256D is a highly altered actinolite-bearing basaltic dike that lacks granoblastic textures, and hence is interpreted to be a late dike that postdates the intrusion of the lower gabbro. Contrary to expectation, porosity increases and $P$-wave velocities decrease stepwise down-

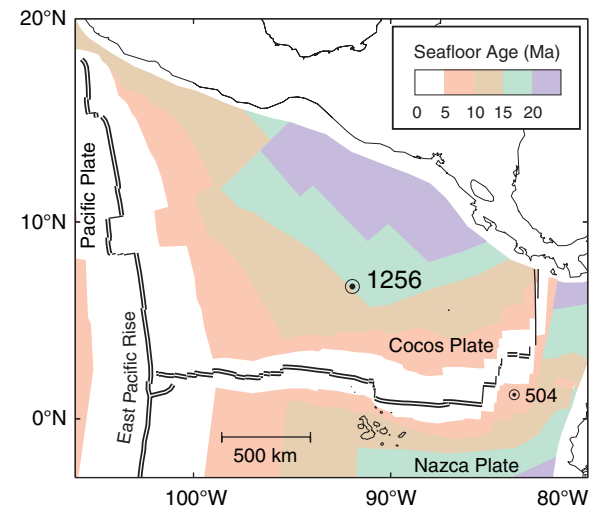

Fig. 2. Age map of the Cocos plate and EPR with isochrons at 5-Ma intervals, converted from magnetic anomaly identifications according to the time scale of Cande and Kent (49). The wide spacing of $10-$ to $20-M a$ isochrons to the south reflects the extremely fast (200 to $220 \mathrm{~mm} / \mathrm{year}$ ) full spreading rate. The locations of deep drill holes into the oceanic crust at Sites 1256 and 504 are shown. 
ward from the lowermost dikes into the uppermost gabbro at Hole 1256D. This results from the contact metamorphism of the granoblastic dikes and the strong hydrothermal alteration of the uppermost gabbros (Fig. 3). Porosity and velocity then increase downhole in the gabbro but are still $<6.5 \mathrm{~km} / \mathrm{s}$.

Flows and dikes from Hole 1256D show a wide range of magmatic fractionation, from fairly primitive to evolved (Figs. 3 and 5). Shallower than 600 mbsf, magma compositions are bimodal, with relatively evolved thick flows and more primitive thin flows. Primitive and evolved compositions are closely juxtaposed within the dikes, as would be expected for vertically intruded magmas. For most major elements and many trace elements, the range of concentrations in flows and dikes is similar to that observed for the northern East Pacific Rise (EPR) (Fig. 5). A few incompatible elements, including $\mathrm{Na}$ and $\mathrm{Zr}$, have lower concentrations than observed for modern EPR lavas, but the substantial overlap of compositions indicates similar processes operated at the superfast-spreading ridge that formed Site 1256 and the modern EPR.

The gabbro compositions span a range similar to the flows and dikes but are on average more primitive. Although less fractionated, the average gabbro composition is evolved relative to candidates for primary magma in equilibrium with mantle olivine. Therefore, the residue removed from primary magma to produce the observed gabbro and basalt compositions must be deeper than the uppermost gabbros penetrated in Hole 1256D.

Discussion. Marine seismologists have long been subdividing the ocean crust into seismic layers: Layer 1 has low velocity and is agreed to be sediments; layer 2 has low velocity and high velocity gradient; layer 3 has high velocity (generally at least $6.7 \mathrm{~km} / \mathrm{s}$ ) and low gradient. There is a widespread perception that layer 3 is equivalent to gabbro, even though Hole 504B penetrated layer 3 but not gabbro $(4,18)$. From regional seismic refraction data the transition from seismic layer 2 to layer 3 at Site 1256 occurs between 1450 to $1750 \mathrm{mbsf}$ (1200 to $1500 \mathrm{msb}$ ) (25) (Fig. 3). Shipboard determinations of seismic velocities of discrete samples are in close agreement with in situ measurements by wireline tools, and the gabbro velocities are $<6.5 \mathrm{~km} / \mathrm{s}$. Downhole velocity measurements end at the top of gabbro, but we interpret the gabbro intervals as within layer 2 because a smoothed extrapolation of the downhole velocities will either have velocities $<6.5 \mathrm{~km} / \mathrm{s}$, still characteristic of layer 2, or will have an exceptionally high gradient to higher velocities, also characteristic of layer 2. Encountering gabbro at a depth clearly within layer 2 reinforces previous suggestions that factors including porosity and alteration are more important than rock type or grain size on controlling the location of the boundary between layers 2 and 3. The position of the dikegabbro boundary, therefore, has little control over the seismic velocity structure of the crust $(4,18)$.

Relative to other well-studied upper ocean crust sections (31), Site 1256 shows a thick lava sequence and a thin dike sequence. Steady-state thermal models require that the conductive lid separating magma from rapidly circulating seawater thins as spreading rate

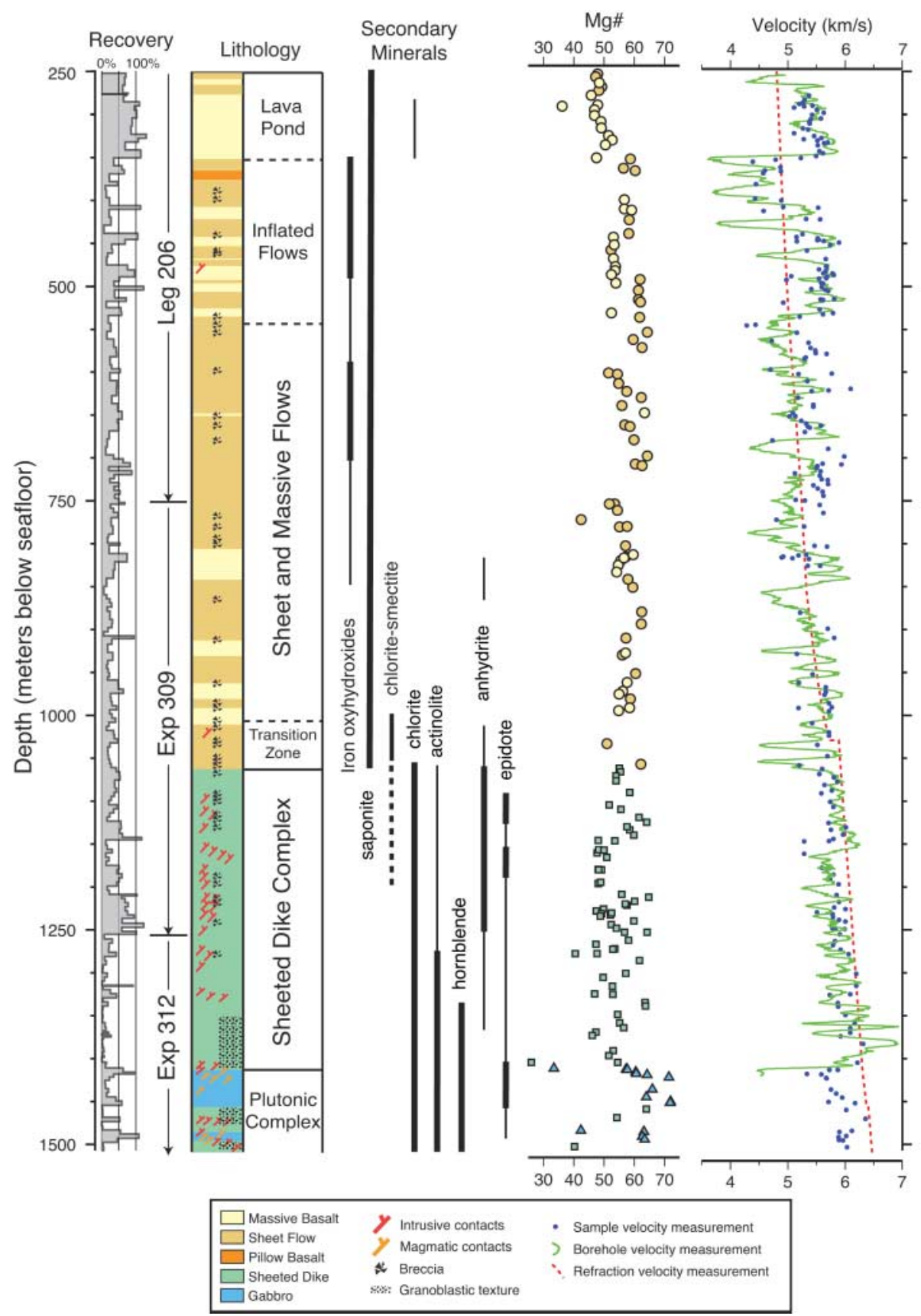

Fig. 3. Summary lithostratigraphic column of the basement drilled to date at Site 1256 showing recovery, major lithologies, downcore index alteration mineral distribution (thick lines show abundant distribution; thin lines show rare distribution), downcore distribution of $\mathrm{Mg}$ number [where $\mathrm{Mg}$ number $=100 \times \mathrm{Mg} /(\mathrm{Mg}+0.9 \times \mathrm{Fe})$ atomic ratio; symbols as in Fig. 5], and seismic velocity measured on discrete samples, by wireline tools, and by seismic refraction (25). 
fast-spread crust exposed in Hess Deep (33), which suggest that regions of high magma supply should have thin lavas and thick dikes. Similarly, there is little evidence for tilting (at most a few degrees) in Hole $1256 \mathrm{D}$ and no evidence for substantial faulting. In contrast, the upper crust exposed at Hess Deep shows substantial faulting and rotations within the dike complex (33). The ponded flow at Site 1256 indicates that faults of $\sim 50$ to $100 \mathrm{~m}$ must exist in superfast-spread crust to provide the necessary relief for ponding of the flow, but faulting and rotations in the dike section must be less common than in crust formed at fast spreading rates, if observations from Hess Deep are widely applicable.

The simplest model for mid-ocean ridge magma plumbing is that the melt lens imaged by MCS is the magma chamber in which crystalrich residues are separated from the evolved lavas that reach the seafloor. The upper gabbro, when partially molten, would have had depth
Fig. 4. (A) Schematic lithostratigraphic section of the Plutonic Complex from the lower portion of Hole $1256 \mathrm{D}$ with representative photographs of key samples. The distribution of rock types is expanded proportionately in zones of incomplete recovery. Felsic plutonic rocks include quartz-rich oxide diorite and trondhjemite. (B) Photomicrograph of a dike completely recrystallized to a granoblastic association of equant secondary plagioclase, clinopyroxene, magnetite, and ilmenite. Some granoblastic dikes have minor orthopyroxene. (C) The dike-gabbro boundary: Medium-grained oxide gabbro is intruded into granoblastically recrystallized dike along an irregular moderately dipping contact. The gabbro is strongly hydrothermally altered. (D) Quartz-rich oxide diorite strongly altered to actinolitic hornblende, secondary plagioclase, epidote, and chlorite. Epidote occurs in $\sim 5$-mm clots in the finer grained leucocratic portions of the rock. (E) Disseminated oxide gabbro with patchy texture and centimeter-scale dark ophitically intergrown clinopyroxene and plagioclase patches separated by irregular, more highly altered leucocratic zones. (F) Medium-grained strongly hydrothermally altered gabbro. The sample is cut by several chlorite + actinolite veins with light gray halos. Plagioclase is replaced by secondary plagioclase and clinopyroxene by amphibole. (G) Clast of partially resorbed dike within gabbro.

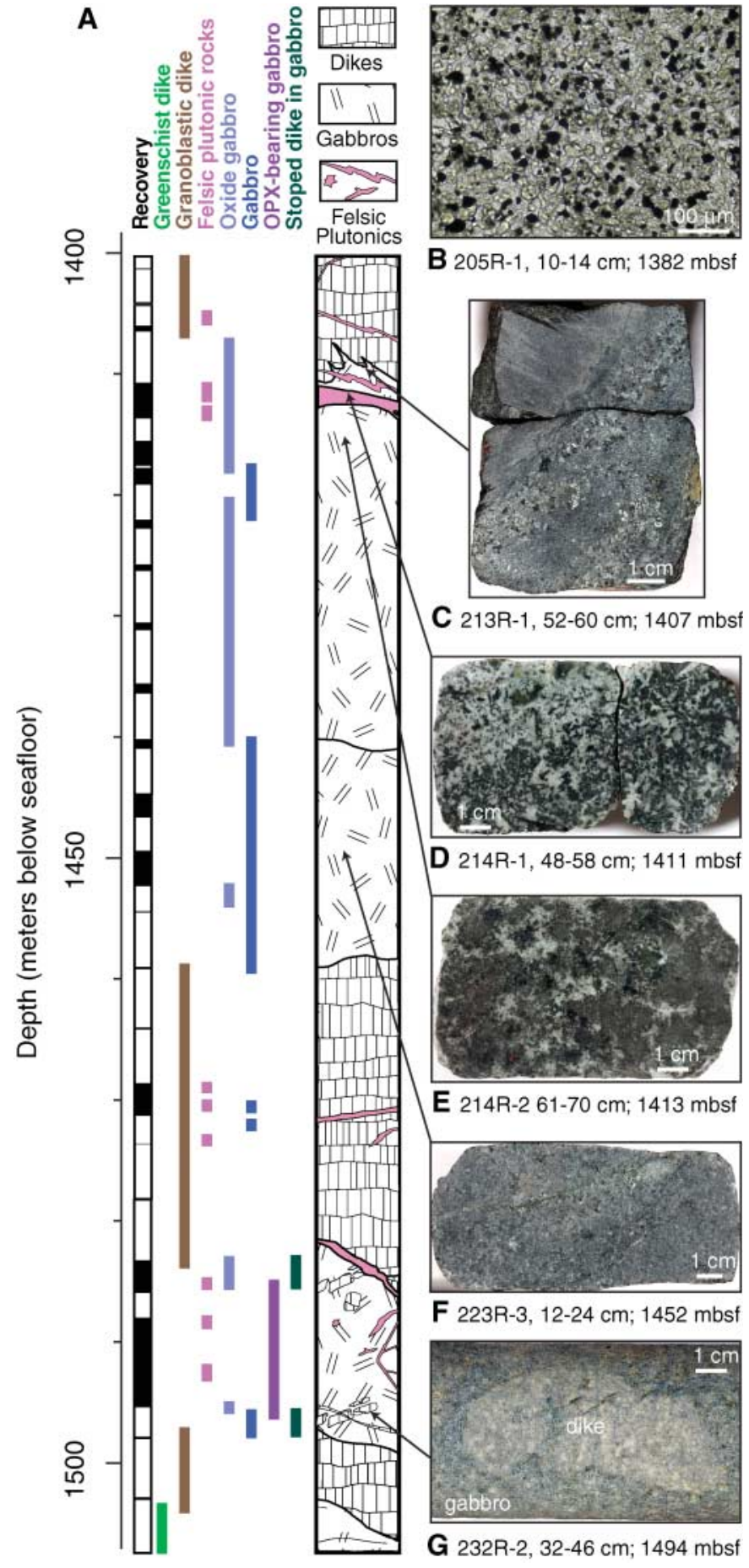

G 232R-2, 32-46 cm; $1494 \mathrm{mbsf}$ and impedance properties consistent with geophysically imaged melt lenses (14) based on trends established for active ridges (Fig. 1). If the upper gabbro intruded on axis and extended roughly horizontally for at least hundreds of meters, its MCS image would look exactly like modern melt lens reflectors, yet it could not have been the site of fractionation. Its chilled margin against the underlying dike screen precludes segregating a crystal residue that subsides to form the lower crust as in the gabbro glacier model, and its fractionated composition requires that crystals have been segregated elsewhere. This implies that sills or other bodies containing cumulate materials must exist deeper in the crust and/or below the boundary between crust mantle, consistent with recent models based on lower crustal sections of ophiolites $(5,17)$ and some marine geophysical experiments (34-37). However, the gabbro glacier mode of accretion cannot yet be rejected because fractionated gabbros in the dike-gabbro transition are not unexpected, and the predicted region of cumulate rocks could still exist just below the present maximum depth of Hole 1256D.

The $~ 800$-m-thick lava sequence is much less hydrothermally altered than other basement sites [e.g., Sites 417 and 418 and Holes 504B and $896 \mathrm{~A}(25,38)]$, and the systematic change with depth from oxidizing to reducing seawater alteration in the upper lavas found elsewhere does not occur. Instead, oxidizing alteration occurs irregularly, associated with steeply dipping vein networks, indicating a structural control of alteration rather than simply decreasing seawater influence downward. The secondary mineralogy of the rocks indicates a stepwise increase in alteration temperatures downhole from $\sim 100^{\circ} \mathrm{C}$ in the lavas to $\sim 250^{\circ} \mathrm{C}$ in the uppermost dikes. Aside from the granoblastic

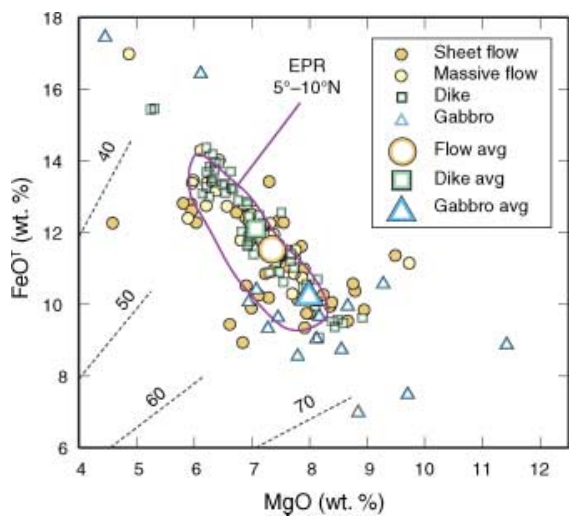

Fig. 5. $\mathrm{FeO}^{\top}$ (total Fe expressed as $\mathrm{FeO}$ ) versus $\mathrm{MgO}$ for the basement at Site 1256, compared with analyses of northern EPR (outline) (50). Dashed lines show constant Mg number. Possible primary mantle melt compositions should have $\mathrm{Mg}$ number of 70 to 78 and $\mathrm{MgO}$ of 9 to 14 weight \%. All flows and dikes and most gabbros are too evolved to be candidates for primary magmas. 
contact metamorphic assemblages in the basal dikes, hydrothermal mineralogy and inferred alteration temperatures of the lower dikes in Hole $1256 \mathrm{D}$ are generally similar to those in the lower dikes of Hole 504B (up to $\sim 400^{\circ} \mathrm{C}$ ). However, the dike section at Site 1256 is much thinner than the section at Site 504 ( 350 compared with $>1000 \mathrm{~m}$ ), which indicates a much steeper hydrothermal temperature gradient at Site $1256\left(\sim 0.5^{\circ} \mathrm{C} / \mathrm{m}\right.$ compared with $0.16^{\circ} \mathrm{C} / \mathrm{m}$ in 504B).

Forming the lower oceanic crust through the crystallization and subsidence of a highlevel melt lens $(6,7)$ is the most efficient geometry for hydrothermal cooling of the crust, as the latent and sensible heat can be readily advected by shallowly circulating hydrothermal fluids. However, models have predicted larger hydrothermal fluid fluxes and more intense alteration than those that have been documented from ocean crustal sections to date (39-41). Epidosites-equigranular epidote-quartz-titanite rocks that delineate zones of intense hydrothermal leaching and channel-ways of upwelling black smoker-type fluids - are common in ophiolites around the dike-gabbro boundary $(42-44)$ and are recorded in the oceans from fore-arc crust (45). Although epidote is a common replacement mineral within and below the transition zone in Hole 1256D (Fig. 3) and rare epidoterich alteration patches are present, epidosites were not recovered. Because of the retrograde solubility of calcium sulfate, anhydrite precipitation must play a critical but to date poorly understood role in axial hydrothermal circulation $(46,47)$. Anhydrite is more abundant in the lava-dike transition and in the upper dikes in Hole 1256D (Fig. 3) compared with Hole 504B (47), but still present in much lower quantities than predicted by numerical models of hydrothermal circulation resulting from the crystallization of the crust in an axial melt lens (46).

The question of whether the lower crust solidifies by shallow crystallization and subsidence $(6)$ or in situ crystallization cooled by deep hydrothermal circulation (9) remains unresolved. The former model requires more intense hydrothermal circulation above a shallow magma chamber to remove the latent heat from crystallizing the lower crust; the latter requires less shallow circulation but more total circulation to remove both latent and sensible heat from the lower crust. The high thermal gradient inferred for the dike layer appears adequate to conduct latent heat of crystallization from a shallow magma chamber, but evidence such as epidosites for the large volume of water required to react with hot rock to sustain this thermal gradient is lacking. Also, the inferred thermal gradient may not reflect steady-state conditions, with high temperatures at depth possibly transitory as the shallow gabbro crystallized. However, evidence for the large volumes of water that must pass through the upper crust to reach and cool the lower crust is also lacking. Retrograde metamorphism under strongly hydrous conditions would be expected below about $1000 \mathrm{msb}$ as large volumes of water quenched the upper crust before circulating at depth.

The penetration of the dike-gabbro boundary in intact oceanic crust is a major milestone that has taken more than four decades of scientific ocean drilling that began with Operation MoHole (48). Our success shows that deep drilling in young ocean crust formed at fast spreading rates is feasible. Such deep drill holes are key to testing models of crustal accretion and calibrating observations from marine geophysics and ophiolites. The shallow depth to gabbros at Site 1256 was predicted from seismic studies of modern active ridges by extrapolation to a spreading rate substantially faster than that occurring on the planet today. Further deepening of Hole $1256 \mathrm{D}$ will challenge current ideas on the formation and cooling of the lower crust, for example, testing the hypothesis that seismic layer 3 at this site consists of relatively impermeable fresh gabbro that cooled by conduction.

\section{References and Notes}

1. J. M. Sinton, R. S. Detrick, J. Geophys. Res. 97, 197 (1992).

2. D. R. Toomey, G. M. Purdy, S. C. Solomon, W. S. D. Wilcock, Nature 347, 639 (1990).

3. E. E. Vera et al., J. Geophys. Res. 95, 15529 (1990)

4. R. S. Detrick, ]. A. Collins, R. A. Stephen, S. A. Swift, Nature 370, 288 (1994).

5. C. J. MacLeod, G. Yoauancq, Earth Planet. Sci. Lett. 176, 357 (2000).

6. T. J. Henstock, A. W. Woods, R. S. White, J. Geophys. Res. 98, 4143 (1993).

7. J. Phipps Morgan, Y. J. Chen, J. Geophys. Res. 98, 6283 (1993).

8. J. E. Quick, R. P. Denlinger, J. Geophys. Res. 98, 14015 (1993).

9. J. Maclennan, T. Hulme, S. C. Singh, Geology 33, 357 (2005).

10. R. S. Detrick et al., Nature 326, 35 (1987).

11. R. S. Detrick et al., Science 259, 499 (1993).

12. G. M. Kent, A. ]. Harding, ]. A. Orcutt, Nature 344, 650 (1990).

13. J. C. Mutter et al., Nature 336, 156 (1988).

14. S. C. Singh, G. M. Kent, ]. S. Collier, A. ]. Harding, J. A. Orcutt, Nature 394, 874 (1998).

15. S. Carbotte, C. Mutter, ]. C. Mutter, G. Ponce-Correa, Geology 26, 455 (1997).

16. G. M. Purdy, L. S. L. Kong, G. L. Christeson, S. C. Solomon, Nature 355, 815 (1992).

17. P. B. Kelemen, K. Koga, N. Shimizu, Earth Planet. Sci. Lett. 146, 475 (1997).

18. J. C. Alt et al., Proc. ODP Sci. Res. 148, 417 (1996)

19. H. J. B. Dick, J. H. Natland, D. J. Miller et al., Proceedings of the Ocean Drilling Program, Initial Reports (Ocean Drilling Program, College Station, TX, 1999), vol. 176, [CD-ROM].

20. P. B. Kelemen, E. Kikawa, D. J. Miller et al., Proceedings of the Ocean Drilling Program Initial Reports (Ocean Drilling Program, College Station, TX, 2004), vol. 209, [CD-ROM].

21. K. Gillis et al., Proceedings of the Ocean Drilling Program, Initial Reports (Ocean Drilling Program, College Station, TX, 1993), vol. 147.
22. Expedition 304 Scientists, IODP Prel. Rep. 304, 10.2204/ iodp.pr.304.2005 (2005).

23. Expedition 305 Scientists, IODP Prel. Rep. 305, 10.2204/ iodp.pr.305.2005 (2005).

24. D. S. Wilson, Geophys. Res. Lett. 23, 3003 (1996).

25. D. S. Wilson et al., Proc. ODP Init. Repts. (Ocean Drilling Program, College Station, TX, 2003), vol. 206 [CD-ROM].

26. Expedition 309 Scientists, IODP Prel. Rep. 309, 10.2204/ iodp.pr.309.2005 (2005).

27. Expedition 309 and 312 Scientists, IODP Prel. Rep. 312, 10.2204/iodp.pr.312.2006 (2006).

28. K. C. Macdonald, P. ]. Fox, R. T. Alexander, R. Pockalny, P. Gente, Nature 380, 125 (1996).

29. S. Umino, S. Obata, P. W. Lipman, Geology 28, 503 (2000)

30. E. Hallenborg, A. J. Harding, G. M. Kent, D. S. Wilson, J. Geophys. Res. 108, 2532 10.1029/2003]B002400 (2003).

31. J. A. Karson, Annu. Rev. Earth Planet. Sci. 30, 347 (2002).

32. S. M. White, R. M. Haymon, D. J. Fornari, M. R. Perfit, K. C. Macdonald, J. Geophys. Res. 107, 2173 10.1029/ 2001]B000571 (2002).

33. J. A. Karson et al., Geochem. Geophys. Geosyst. 3, 1002 10.1029/2001GC000155 (2002).

34. W. C. Crawford, S. C. Webb, Earth Planet. Sci. Lett. 203, 117 (2002).

35. R. A. Dunn, D. R. Toomey, R. S. Detrick, W. S. D. Wilcock, Science 291, 1955 (2001).

36. J. Garmany, Nature 340, 628 (1989).

37. M. R. Nedimovic et al., Nature 436, 1149 (2005).

38. J. C. Alt, in Hydrogeology of the Oceanic Lithosphere, H. Elderfield, E. Davis, Eds. (Cambridge Univ. Press, New York, 2004), pp. 456-488.

39. J. C. Alt, D. A. H. Teagle, Geol. Soc. Am. Spec. Pap. 349 (2000), pp. 273-282.

40. K. M. Gillis, L. A. Coogan, R. Pedersen, Earth Planet. Sci. Lett. 232, 83 (2005).

41. D. A. H. Teagle, M. J. Bickle, J. C. Alt, Earth Planet. Sci. Lett. 210, 81 (2003).

42. P. Nehlig, T. Juteau, V. Bendel, ]. Cotten, J. Geophys. Res. 99, 4703 (1994).

43. C. J. Richardson, ]. R. Cann, H. G. Richards, ]. G. Cowan, Earth Planet. Sci. Lett. 84, 243 (1987).

44. P. Schiffman, B. M. Smith, R. J. Varga, E. M. Moores, Nature 325, 423 (1987)

45. N. R. Banerjee, K. M. Gillis, K. Muehlenbachs, Geology 28, 151 (2000).

46. N. H. Sleep, J. Geophys. Res. 96, 2375 (1991).

47. D. A. H. Teagle, J. C. Alt, A. N. Halliday, Earth Planet. Sci. Lett. 155, 167 (1998)

48. W. Bascom, A Hole in the Bottom of the Sea (Doubleday and Co., New York, 1961), pp. 352.

49. S. C. Cande, D. V. Kent, J. Geophys. Res. 100, 6093 (1995).

50. C. H. Langmuir, ]. F. Bender, R. Batiza, Nature 322, 422 (1986).

51. This research used samples and data provided by the ODP and the IODP. ODP was sponsored by the NSF and participating countries under management of Joint Oceanographic Institutions (JOI), Inc. IODP is supported by NSF; Japan's Ministry of Education, Culture, Sports, Science, and Technology; the European Consortium for Ocean Research Drilling; and the People's Republic of China, Ministry of Science and Technology. For Leg 206, D.S.W. and D.A.H.T. were co-chief scientists, and G.D.A. was the staff scientist. For Expedition 309, D.A.H.T. and S.U. were co-chief scientists, and N.R.B. was the staff scientist. For Expedition 312, J.C.A. and S.M. were co-chief scientists, and N.R.B. was the staff scientist. We thank JOIDES Resolution Captains P. Mowat and A. Simpson, Drilling Superintendents Tim McCown and Wayne Malone, Operations Superintendents R. Grout and K. Grigar, the entire transocean crew, and the Texas A\&M University technical staff from ODP Leg 206 and IODP Expeditions 309 and 312 for successful operations.

10 February 2006; accepted 6 April 2006

Published online 20 April 2006;

$10.1126 /$ science. 1126090

Include this information when citing this paper. 